\title{
Exemplary Models of Faculty-Driven Transformative Diversity Education Initiatives: Implications for Metropolitan Universities
}

\author{
Chaunda L. Scott and Jeanetta D. Sims
}

\begin{abstract}
Diversity and diversity education are driving forces in metropolitan universities that seek stronger alignment with nearby metropolitan statistical areas. As a result, many metropolitan universities wish to engage in diversity efforts; however, they often lack the resources for doing so. In addition, institutional efforts are often the result of administrative-originated programs of diversity impact rather than faculty-driven curricular and co-curricular efforts (Scott \& Sims, 2016). In this case study, the authors offer two faculty-driven diversity programs with a proven record of accomplishment as models of transformative learning practice for faculty and institutions to replicate. The programs have been in existence for more than 10 years and have benefited both the students and universities alike.
\end{abstract}

Keywords: transformative learning; Diverse Voice Conference; Oakland University; diverse student scholars; University of Central Oklahoma; undergraduate student research

\section{Introduction}

"True diversity remains a struggle for many colleges." -("Diversity in academe," 2016)

Metropolitan statistical areas (MSAs) typically include large populations of people who represent a diverse set of identities based on age, ethnicity, race, religion, sexual orientation, and other areas of identification. Metropolitan universities, which are educational institutions located near MSAs, are challenged with adequately accomplishing workforce diversity learning, which involves equipping students with core workforce diversity competencies (see Lahiri, 2008 for a model of seven core workforce diversity competencies with associated proficiency areas). Many authors have previously summarized the facets of workforce diversity programs, curriculum, and degrees needed in higher education (see Scott \& Sims, 2016 for exemplars of current and future workforce-diversity efforts in higher education). Moreover, overall workforce diversity learning in academe has not kept pace with corporate counterparts (Scott \& Sims, 2014).

The authors argue that metropolitan universities, in particular, have a unique opportunity to address the void of students' professional readiness for workforce diversity and the dearth of programs that build students' workforce-diversity competencies. Through the lens of transformative learning, this manuscript discusses two impactful programs (Diverse Voices Conference and Diverse Student Scholars) that enable students to transform their understanding of others from different identities and of workforce diversity itself. Diverse Voices Conference is a supportive forum for students, faculty, professionals, and community members hosted at Oakland University (OU). Diverse Student Scholars is a robust program of undergraduate 
research engagement housed at the University of Central Oklahoma (UCO). Both are facultyfounded initiatives that stem from the scholars’ commitment to directly contributing to workforce diversity learning.

This paper begins with a review of transformative learning theory and diversity initiatives in higher education. Then a discussion of the value of faculty-driven efforts introduces a summary of two diversity program exemplars. Finally, the paper offers the implications for metropolitan universities tasked with equipping students to contribute in MSAs.

\section{The Role of Transformative Learning Theory}

Mezirow’s (1991) transformative learning theory explains how adults learn from their experiences. The theory proposes that learning occurs when individuals make meaning of an experience, which gives breath to that experience. It helps individuals to understand their past, current and new experiences. Mezirow defines meaning in the context of meaning perspectives, which he defined as the "habits of expectation" that serve as the "interpretive codes" through which meaning is made (p. 4). Mezirow's (1991) theory offered the following four ways that learning can occur: (a) learning can take place when one explains an existing meaning scheme; (b) learning can occur when one acquires new meaning schemes in the form of new knowledge and attitudes; (c) learning can take place when one acquires new skills that fit into one's existing meaning perspectives; and (d) learning can occur when one can alter meaning schemes when experiences no longer support a current attitude, belief, or a point of view.

According to Mezirow, individuals reflect on the triggering assumptions that supported the previous view and modify the meaning schemes. As time passes, meaning perspectives may evolve through an assortment of changed meaning schemes. A key facet of how learning can transpire is through perspective transformation. This occurs when one experiences a major life experience (such as a death, illness, or loss of a job), which Mezirow called a disorienting dilemma. According to Mezirow, a disorienting dilemma can cause individuals to reconsider their existing meaning perspective, which can bring about a change in that perspective (Mezirow, 1991).

The final facet of learning offered by Mezirow (1991) is emancipatory learning, which uses reflection to identify and challenge distorted meaning perspectives. "Emancipatory knowledge is knowledge acquired through critical self-reflection and supported by communication with others that allows one to test the insights [they] have acquired through reflection” (p. 87). By engaging in the process of critical reflection and rational discussions with others, adults can develop meaning perspectives that are more inclusive, diverse in perspectives, and integrative of experience.

Though Mezirow's work has been challenged, expanded, and modified through the years (see Dirkx, Mezirow, \& Cranton, 2006 and Kitchenham, 2008), it remains a central seminal work on explaining learner transformation. For purposes of this manuscript, learning from experience involves altering one's meaning schemes and changing one's meaning perspectives, possibly through both gradual accumulation of changed meaning schemes and perspective transformation. Thus, Mezirow's (1991) theory of transformative learning is a useful basis for understanding 
how faculty-driven diversity initiatives at metropolitan universities can contribute to transforming student's knowledge, skills and abilities in the areas of human diversity and workforce diversity. Next, this manuscript discusses the importance of these types of diversity education initiatives in higher education institutions.

\section{The Importance of Diversity Education Initiatives in Higher Education Institutions}

According to the American Council on Education (2012) "collective diversity among institutions is one of the greatest strengths of America's higher education system” (para, 8). Institutions of higher education appear to agree as many have adopted (need a verb: elevating, expanding, embracing, etc) diversity as a core institutional value (citation). These institutions are supporting the integration of diversity practices such as diverse recruitment efforts for students as well as faculty and staff at all levels, diversity courses, diverse student services and diversity programming. The institutions' main rationale for this increased emphasis on diversity is the realization that all students today need exposure to diversity through learning and social activities so they can be prepared to live, work and thrive productively and respectfully in a diverse global society. Additional reasons supporting the need for diversity in higher education institutions offered by the American Council on Education (2012) include:

- Diversity enriches students' educational experiences by being exposed to students from diverse backgrounds.

- Diversity promotes personal growth and a healthy society by dismantling preconceived negative views about cultures and ethnicities that are unfamiliar.

- Diversity strengthens communities and the workplace by preparing students to be contributing members of society.

- Diversity enhances America's economic competitiveness by developing the potential of students from all cultural backgrounds

The Center for American Progress (2012) also offers several reasons why diversity is important on university campuses. First, rapidly changing demographics in our society have made it clear that higher education settings need to be prepared to serve and educate a growing number of minorities. Second, diversity helps all students by enhancing their cultural awareness, social skills, academic attainment and their diverse relationships. Third, changing demographics in our society also implies that unbiased practices in higher education settings help to afford opportunities for all students to succeed academically. As the demographic make-up of society continues to evolve, metropolitan universities should aim to mirror this demographic shift. In this way, all of their students will better understand the important role diversity plays in their lives as a college student and beyond graduation.

Given the increased importance of diversity in higher education, student-focused diversity initiatives become an integral and valued part of the college student experience. These initiatives can play a vital role in providing evidence of the much-needed diversity deliverables capable of generating new meaning schemes or altering existing schemes. In addition, student-focused diversity initiatives can help generate emancipatory knowledge and perspective formation. Next, this article discusses the value of faculty-driven, as opposed to administrative-originated diversity initiatives. 


\section{The Need for Faculty-Driven Diversity Initiatives in Metropolitan Communities}

Faculty are key threads in the fabric of higher education institutions. Thus, faculty play a pivotal role in advancing workforce diversity learning. In institutions where we have served, faculty are credited with driving curriculum decisions in degree programs, and many individuals will leave the ranks of faculty to work in administrative leadership where they will exert key influence over shaping institutional mission and vision. Thus, in addition to the distinctive roles faculty fill in higher education institutions, we contend that faculty, more so than administrators, are uniquely suited for advancing diversity initiatives in higher education, particularly in metropolitan areas.

Though not as proportionate as desirable, the diversity of faculty in institutions of higher education is often greater than the diversity of administrative leadership in the same institutions. "Changes in the demographics of individuals in academia, particularly in the faculty and administrative ranks, have been much slower than anticipated (Whittaker \& Montgomery, 2014, p. 264);" however, the presence of a more diverse faculty positions this group to make a greater contribution in the area of diversity initiatives.

Faculty-driven diversity initiatives have a greater likelihood of sustainability since faculty are more prone to commit to the time investment, resource engagement, and external funding submissions needed for the continued support of the diversity programming that they create. Faculty often build their careers around an investment in their students, in programs of research, and in their disciplines. The ability and desire of faculty to link their personal academic interests to diversity initiative engagement enables the diversity programming to grow with faculty.

Next, faculty-driven diversity initiatives, unlike administrative interests, often stem from creative teaching and research ideas or activities arising from the interests of faculty. This results in a direct connection between diversity initiatives and key academic functions of the metropolitan university. Diversity-linked research and teaching efforts can increase course enrollment, improve in-classroom student learning, and stimulate student learning beyond the classroom. When teaching becomes a part of diversity initiatives, faculty become engaged in a central institutional function that links their diversity activities to tenure and promotion.

Faculty-driven diversity initiatives have the potential for greater heuristic value and metro-area impact. The stimulation of academic clusters, centers, or institutes enable faculty to collaborate when guided by similar interests. These types of temporary or permanent faculty initiatives may focus on teaching, research, or other areas linked to a metro-area need. For purposes of this manuscript, interdisciplinary academic clusters involve interdisciplinary teams of faculty who have made a commitment to pursue a common area of interest in an effort to fulfill a metro-area need (see Sims, 2015). For examples of cluster-initiated activity, see Dartmouth College and Oakland University as examples.

The authors contend that student-focused diversity initiatives that are developed and sustained by faculty are ideal and desirable for institutional engagement with metropolitan communities. Faculty-driven initiatives are more likely to persist after implementation. They have a greater potential to link to academic functions of institutions and of informing tenure and promotion 
processes. Finally, faculty-driven initiatives can spur interdisciplinary interactions that foster broader levels of engagement and impact. Here, this article highlights two faculty-driven diversity initiatives.

\section{Two Exemplary Models of Faculty-Driven Student Diversity Engagement}

Given the importance of diversity education initiatives in higher education as well as the benefits of faculty-driven diversity initiatives, this section provides an overview of two diversity initiatives developed by faculty for the purposes of stimulating student engagement and transformative learning. Both programs occur at metropolitan universities with the intent of having an impact on workforce diversity learning. Though they are distinct, both represent the main functions of faculty scholarship and engagement through their emphasis on teaching and research.

\section{Example One: The Diverse Voices Conference}

In 1998, Dr. Chaunda Scott developed the Diverse Voices Conference (DVC) on paper as an innovative, experiential, and extracurricular higher education initiative. The goals of the DVC are to provide higher education student presenters, renowned scholars, professionals and community members with a supportive forum to speak out in support of valuing all aspects of human diversity and engage in dialogue on real world diversity issues annually. Moreover, the DVC expands diversity education beyond the classroom into a town forum-like setting to broaden the dialog on the importance of human diversity and workforce diversity in our society (Scott, 2014).

The founder was inspired to develop the DVC following the realization that higher education students have limited opportunities to discuss and learn from the real-world diversity issues they see on television and read about on the internet. This is partially due to the sensitive nature of many real-world diversity issues such as race, sexism, ethnicity, racism, immigration and homophobia to name a few. Moreover, the majority of faculty members who teach diversity courses have not been educated and trained on how to lead and manage such sensitive discussions in the classroom; this is because diversity education and training was not a part of their academic studies. In an attempt to address this diversity education issue in higher education, in 1999, Oakland University (OU) in Rochester, Michigan launched its first DVC. OU is a predominately-white metropolitan "student-centered doctoral research institution that encourages faculty-driven and student-engaged research, scholarship and creative activities” (Oakland University Mission, 2017). The total student population at OU stands at 20,020 (Oakland University Fast Facts. 2017). Because OU supports the development of faculty-led innovative pursuits that engage students, especially in the area of diversity, the DVC has continued to flourish for nearly two decades towards advancing diversity education, student-centered work.

As a unique annual program, the DVC always takes place on a Saturday morning on OU's campus in a large auditorium from 10 a.m. to 1 p.m., which does not compete with weekday class times and thus allows more students as well as faculty, staff, professionals and community members to attend. The DVC is also free to attend, open to the public, and funded by OU at the rate of \$1,500-\$3,000 annually, which includes in-kind support. To date, 60 OU students from diverse backgrounds have presented at the DVC over a 15-year period, and more than 4,000 
diverse students, faculty, staff, professionals and community members have attended a DVC during this period. The DVC design takes away the fear of being "graded” so that students can fully connect with, participate in, and enjoy the DVC experience. DVC utilizes a variety of cultural influences such as poetry, music, singing and dance performances to enhance the learning experiences of all attendees. Additionally, each DVC concludes with networking opportunities and refreshments.

In terms of impact, the DVC provides an opportunity for students to revise their human diversity and workforce diversity meaning schemes and habits of mind (Mezirow, 1991); through the oneday event students advance their diversity consciousness as it relates to the development of new positive ways of understanding human diversity and workforce diversity concepts and issues. Moreover, the DVC advances student learning in the focused areas of human diversity and workforce diversity while promoting community engagement, networking opportunities critical thinking, and professional presentation skills. Several parents of DVC student presenters over the past 15 years have also stated that they enjoyed having an opportunity to observe their child in the role of an intellectual orator.

The DVC has received numerous awards including: the Diversity Champion Award presented by the Race Relations and Diversity Task Force of Birmingham/Bloomfield, MI (2005); the Advisor of the Year Award presented by Oakland University (2007); the Presidential Diversity Award presented by Oakland University (2008); and the Educator of the Year Award presented by the Niagara Foundation - Michigan Chapter (2015). In 2015, the DVC model was introduced at Cape Peninsula University of Technology (CPUT) in Cape Town, South Africa as a premier faculty-driven, student-centered diversity initiative that can be replicated and utilized to advance diversity programming at CPUT as well as at other higher education institutions throughout South Africa.

At each of the past 15 DVCs, the organizers have distributed a feedback survey at the end of each conference. The purpose of the survey is to assess the effectiveness of the program by measuring the extent and modes to which the the program influenced the students, both presenters and attendees. The survey data also serve efforts to revise, improve, and create future student-centered Diverse Voices Programs. Although the survey goes to every person in attendance, the student feedback is most important, because the focus of the DVC is on OU and Michigan higher education students furthering their awareness and understanding of human diversity and workforce diversity. Key student suggestions from recent survey data involve adding more student speakers, more refreshments and more student-led cultural entertainment from OU and the greater Detroit metropolitan community.

Within the next three years, organizers plan to expand the DVC into a full-day Saturday conference. Within the next five years, OU intends to expand the DVC into an international student-centered diversity conference. An international conference would require that operating costs of the DVC increase by as much as $\$ 3,000-\$ 5,000$. Based on the success of the DVC to date, if the DVC becomes an international initiative, students from all backgrounds will continue to attend, participate and learn about the importance of valuing human diversity and workforce diversity. The DVC international opportunity can further result in student presenters and student 
attendees alike being better informed and more prepared before they graduate on how to live, work and play more respectfully and productively in our multicultural world.

Example Two: The Diverse Student Scholars Program

The work of Diverse Student Scholars began in fall 2007 with Dr. Jeanetta D. Sims’ appointment to a faculty position in the marketing department of the College of Business at the University of Central Oklahoma (UCO). Dr. Sims saw the need to link faculty endeavors (see Sims, 2011, p. 36-37) related to research and diversity with the institution's academic mission on transformative learning (see Barthell, Chen et al., 2013 and Barthell, Cunliff et al., 2010). Diverse Students Scholars began, accordingly, as a mostly undergraduate interdisciplinary research program of student engagement that permitted the faculty member's program of research in the areas of workforce diversity, strategic communication, marketing, persuasion and social influence to serve as the foundation for scholarly inquiry with students. Diverse Student Scholars started with just a single student enrolled in an independent study. Eleven years later, the program has now grown to involve more than 60 students, with as few as one to as many as 21 students engaged in research projects in a single semester.

Through ongoing research project involvement, Diverse Student Scholars seeks to increase the presence of women and people of color in higher education through exposing more students to a key element of faculty academic life - research. In addition, a key desire is to accomplish this through engaging students from different identities to work on various research projects linked loosely to the faculty member's existing program of research. The three-fold mission of Diverse Student Scholars involves: (a) engaging students in the research pipeline process; (b) enhancing students' cognitive, affective, and behavioral skills for both research and professional career preparation; and (c) cultivating students' abilities at interacting and working with people from different identities.

Along with the institutional emphasis on transformative learning, Diverse Student Scholars has grown in tandem with UCO's institutional focus on undergraduate research specifically. In 2015, UCO won its bid to host the 2018 National Conference on Undergraduate Research. Through the institutional resources and opportunities provided in faculty appointments, Diverse Student Scholars has received funding through faculty on-campus research grants, student on-campus research grants, on-campus Student Transformative Learning Record (STLR) grants, and an oncampus Transformative Learning Scholar appointment. From these university-level resources, Diverse Student Scholars has persisted amid a College of Business culture with low levels of undergraduate research engagement in comparison to other Colleges on the UCO campus. The low level of undergraduate research engagement among professional schools, like schools of business is not unique to UCO but represents a national trend (see Sims, Shuff, Neese, Lai, Lim, et al., 2016 and the Council on Undergraduate Research Quarterly Summer 2015 Issue). This makes the Diverse Student Scholars program unique in its ability to accomplish student-driven interdisciplinary research engagement in a business college.

The work of Diverse Student Scholars typically aligns with the academic calendar and takes place outside of the typical classroom and course structure environments. By research project, the Diverse Student Scholars founder meets with students in one-hour meetings each week. The 
research work concentrates on moving various projects from ideation and design to submission for either client presentation, conference presentation, or journal publication. Between weekly meeting times, students are responsible for completing assignments and performing tasks related to project design, data collection, upcoming presentations, or other research work. Metro-area companies and non-profit organizations have been involved in research projects through students working on projects funded either by grants or through students engaging in projects that develop into conference presentations. Diverse Student Scholars students have presented co-authored research at an international conference (in Cape Town, South Africa), national disciplinary conferences (National Communication Association, Marketing Management Association, North American Management Society, and Greenleaf Center for Servant Leadership), undergraduate student research conferences (National Council on Undergraduate Research), and state-wide conferences (Oklahoma Research Day), along with local metro-area presentations.

Since the program's inception, 100\% of Diverse Student Scholars students (who have worked in the program for one semester) have made at least one co-authored conference presentation. Collectively, Diverse Student Scholars students have achieved over 25 funded student grants, 5 funded faculty grants, more than 80 conference presentations, more than 29 research independent studies, nearly 20 proceedings and journal publications, and 3 national conference top paper awards. This level of research production enables students to showcase their professional and career preparation on their vitas and résumés.

Sims, Anderson, Neese, and Sims (2013) provide a summary of the impact of Diverse Student Scholars on students' affective, cognitive, and behavioral abilities. The outcomes of student impact also include increased professionalism, increased contacts/networks, responsiveness to deadlines, and improved self-efficacy (Sims, Le, Emery, \& Smith, 2012). Additionally, Diverse Student Scholars students are better able to integrate knowledge, work in a team, and use research databases (Sims, Le, \& Smith, 2011). Students of color who were first-generation students with Diverse Student Scholars have reported the outcomes of learning to be a role model and learning to be more persistent because of their engagement in Diverse Student Scholars research (Sims, Anderson, \& Murray, 2012). The representation of students involved in Diverse Student Scholars has been more female (56.82\%) than male (43.18\%) with a higher level of involvement among Black/African American (15.91\%), Asian (9.09\%), and Caucasian (63.64\%) students when compared to the UCO student diversity composition percentages of these racial/ethnic groups (Sims, Shuff, et al., 2016). Numerous dimensions of diversity (e.g., race, ethnicity, gender, religious, sexual orientation, etc.) have appeared among the different identities associated with students engaged in Diverse Student Scholars.

At its 10-year anniversary, the founder has accomplished a number of goals with Diverse Student Scholars with some goals remaining. Along with serving in an elected position as a Council on Undergraduate Research (CUR) Councilor, the mid-range goal of establishing a web presence for Diverse Student Scholars (www.diversestudentscholars.com) was recently accomplished. The website can be a resource for other metro-area faculty and institutions. Fittingly, an undergraduate student research assistant funded from a UCO Student Transformative Learning Record (STLR) grant completed the website design work. Future efforts associated with Diverse Student Scholars involve identifying additional external avenues of sustained support for both student projects and conference presentation travel as well as completing a comprehensive 
evaluation of both program impact and workforce diversity competencies (see Sims, Shuff et al., 2016 and Lahiri's, 2008 model) among students at pre- and post-graduation. An additional aim is for the founder to provide more resources and templates from her work with Diverse Student Scholars to other faculty to assist their efforts in replicating the current model or developing new models of student research engagement.

\section{Overview of Impact from Two Faculty-Driven Diversity Programs at Metropolitan Universities}

Through a teaching focus (Diverse Voices Conference) and research focus (Diverse Student Scholars), the two faculty-driven diversity programs offer unique examples of improving metropolitan university engagement with metro-area communities and organizations. Table 1 summarizes the key features of both programs of impact for replication and consideration by other metropolitan universities. Though distinct and differing in their execution, both programs offer opportunities for student transformation. Both programs also seek to foster a greater level of workforce diversity learning through advancing key workforce diversity competencies.

Table 1. Key Features of Two Faculty-Driven Diversity Programs at Metropolitan Universities

\begin{tabular}{|c|c|c|}
\hline Areas of Impact & $\begin{array}{l}\text { Diverse Voices Conference } \\
\text { Undergraduate and } \\
\text { community forum in its } 15^{\text {th }} \\
\text { year }\end{array}$ & $\begin{array}{c}\text { Diverse Student Scholars } \\
\text { Undergraduate research } \\
\text { engagement in its } 11^{\text {th }} \text { year } \\
\text { www.diversestudentscholars.com } \\
\end{array}$ \\
\hline $\begin{array}{l}\text { Evidence of transformative } \\
\text { learning }\end{array}$ & Yes & Yes \\
\hline $\begin{array}{l}\text { Diversity education } \\
\text { teaching }\end{array}$ & Yes & No \\
\hline Diversity research & No & Yes \\
\hline $\begin{array}{l}\text { Extends diversity learning } \\
\text { beyond the classroom }\end{array}$ & Yes & Yes \\
\hline $\begin{array}{l}\text { Faculty-student } \\
\text { engagement }\end{array}$ & Yes & Yes \\
\hline Relationship-building & Yes & Yes \\
\hline Professional skill-building & Yes & Yes \\
\hline Team-building skills & Yes-for presenters & Yes \\
\hline $\begin{array}{l}\text { Faculty-student time } \\
\text { commitment }\end{array}$ & $\begin{array}{l}\text { Bi-weekly meetings for } \\
\text { six months }\end{array}$ & $\begin{array}{l}\text { Weekly meetings by project } \\
\text { throughout the academic year }\end{array}$ \\
\hline Metro-area engagement & $\begin{array}{c}\text { Yes through a } \\
\text { one-time forum }\end{array}$ & $\begin{array}{l}\text { Yes through research and funded } \\
\text { projects }\end{array}$ \\
\hline Frequency & One forum per year & Continuous projects \\
\hline Avg. annual funding & $\begin{array}{l}\quad \$ 3,000-\$ 5,000 \\
\text { varies by local vs. out-of- } \\
\text { state keynote speaker fees }\end{array}$ & $\begin{array}{c}\$ 3,000-\$ 10,000 \\
\text { varies by number of students } \\
\text { involved and conference travel }\end{array}$ \\
\hline
\end{tabular}

A key aim of this manuscript has been to introduce the Diverse Voices Conference and Diverse Student Scholars as faculty-driven programs capable of influencing student transformative 
learning at metropolitan universities. "Two major elements of transformative learning are critical reflection, or critical self-reflection, on assumptions and critical discourse, where the learner validates a best judgement” (Kitchenham, 2008, p. 105). Table 2 offers evidence of transformative impact from the self-reflections and discourse of students who have engaged in the two programs either as attendees and presenters (for the Diverse Voices Conference) or as research assistants (for Diverse Student Scholars).

Table 2. Sample Evidence of Transformative Learning Impact from Two Faculty-Driven Diversity Programs at Metropolitan Universities

\begin{tabular}{|c|c|}
\hline $\begin{array}{c}\text { Diverse Voices Conference } \\
\text { Evidence of Student Transformative } \\
\text { Learning Impact }\end{array}$ & $\begin{array}{c}\text { Diverse Student Scholars } \\
\text { Evidence of Student Transformative } \\
\text { Learning Impact }\end{array}$ \\
\hline $\begin{array}{l}\text { "Wow ... the Diverse Voices Conference } \\
\text { was great! It reinforced the workforce } \\
\text { diversity concepts we are learning in Dr. } \\
\text { Scott’s workforce diversity course.” }\end{array}$ & $\begin{array}{l}\text { “I have enjoyed being a student, but the } \\
\text { additional events and activities that I've } \\
\text { done have really enriched my educational } \\
\text { experience. In fact, I feel like I've } \\
\text { learned more, and I understand the things } \\
\text { that I'm learning now, because I’ve had } \\
\text { these experiences - especially, the } \\
\text { research.” }\end{array}$ \\
\hline $\begin{array}{l}\text { "It was an outstanding student centered } \\
\text { learning experience. I learned a lot about } \\
\text { how the presenters understand human } \\
\text { diversity - along with how I understand } \\
\text { human diversity." }\end{array}$ & $\begin{array}{l}\text { "I've had the benefit of having someone } \\
\text { sit and teach me step-by-step what to do. } \\
\text { I believe every student should have the } \\
\text { opportunity to participate in research and } \\
\text { gain these experiences if at all possible. It } \\
\text { makes a huge difference." }\end{array}$ \\
\hline $\begin{array}{l}\text { "What I liked most about the Diverse Voices } \\
\text { Conference was the student presenters - } \\
\text { which were my classmates. They were so } \\
\text { well spoken, polished and professional. They } \\
\text { all have encouraged me to work on } \\
\text { becoming a better speaker and advocate in } \\
\text { promoting human diversity understanding." }\end{array}$ & $\begin{array}{l}\text { "These experiences beyond the } \\
\text { classroom have made a lasting impact } \\
\text { allowing me to explore cities, meet new } \\
\text { people, and understand other cultures in a } \\
\text { capacity that I would not have otherwise } \\
\text { experienced." }\end{array}$ \\
\hline $\begin{array}{l}\text { "All of the presenters - the student } \\
\text { presenters, faculty presenter, keynote } \\
\text { presenter, along with the interpreter, singers } \\
\text { and dancers provided me with some } \\
\text { interesting viewpoints to consider regarding } \\
\text { how to further my diversity learning along } \\
\text { with what I can do to help eradicate racism } \\
\text { in society!” }\end{array}$ & $\begin{array}{l}\text { "It is an undervalued opportunity for } \\
\text { students to get more out of their } \\
\text { education... Working on research teaches } \\
\text { you three important skills that are crucial } \\
\text { things employers look at when hiring: } \\
\text { responsibility, communication, and } \\
\text { teamwork." }\end{array}$ \\
\hline
\end{tabular}




\section{Implications for Metropolitan Universities}

Metropolitan universities can hasten their diversity efforts by linking institutional diversity efforts with faculty-driven diversity initiatives that promote student engagement. Institutional efforts leveraged with faculty commitment can result in student transformative learning. Achieving this level of productive impact among metropolitan communities does involve key considerations; many of these are discussed in this section.

Various types of resources must provide support and funding for faculty-driven, student-centered diversity initiatives. Metropolitan universities should consider financial support as well as release time for faculty who have demonstrated expertise and a sustained engagement in diversity initiatives. Faculty-driven programs that have a three-year proven record of accomplishment of success should become established on a more permanent basis. In addition, a professional development stipend may be useful to assist faculty in further advancing their diversity knowledge for the implementation of student-centered initiatives. A travel budget could support faculty and student travel, to present program success at local, national, and international conferences.

Along with resources, metropolitan universities will need to encourage the building of relationships through beyond-the-classroom programs of impact. This manuscript offers two exemplars based on community outreach and research. Beyond these programs, other institutions may develop additional student-centered programs, and the extent that they are faculty-driven will permeate greater success.

An additional implication for metropolitan universities is to engage in pockets of thought leadership related to metro-area needs and key diversity issues. This provides an immediate opportunity for faculty to have an additional outlet for their skills and abilities beyond the classroom while also forging direct linkages to racial and ethnic groups within the metropolitan area.

Finally, an additional consideration is for metropolitan universities to link faculty-driven diversity initiatives to institutional tenure and promotion processes. Student-centered programming that aligns directly to faculty promotion processes provide an extra incentive for faculty engagement; however, diversity initiatives placed in the realm of work that is not linked to tenure and promotion become a barrier for faculty engagement.

\section{Conclusion}

In a time when diversity has become increasingly important in higher education, metropolitan universities are stretched with sustaining relevant, student-centered diversity programming that links the institution to the metropolitan area. This article has offered two faculty-driven diversity initiatives that have successfully accomplished workforce diversity student engagement and transformative learning for a combined total of 25 years. The hope is for these two exemplars to spur more faculty-driven diversity programs capable of helping metropolitan universities and transforming metro-area students. 


\section{References}

American Council on Education (2012). On the importance of diversity in higher education. Retrieved from http://www.acenet.edu/news-room/Documents/BoardDiversityStatementJune2012.pdf

Barthel, J. F., Chen, W. R., Endicott, B. K., Hughes, C. A., Radke, W. J., Simmons, C. K., \& Wilson, G. M. (2013). Encouraging and sustaining a culture of student-centered research at a predominantly undergraduate institution. Council on Undergraduate Research Quarterly, 34(1), 41-47.

Barthel, J. F., Cunliff, E., Gage, K., Radke, W. \& Steele, C. (2010). Transformative learning: Collaborating to enhance student learning. Proceedings of the $115^{\text {th }}$ Annual Meeting of The Higher Learning Commission: A Collection of Papers on Self-Study and Institutional Improvement (26 $6^{\text {th }}$ Ed.). 56-60.

Dirkx, J. M., Mezirow, J., \& Cranton, P. (2006). Musings and reflections on the meaning, context, and process of transformative learning: A dialogue between John M. Dirkx and Jack Mezirow. Journal of Transformative Education, 4(2), 123-139.

https://doi.org/10.1177/1541344606287503

Diversity in academe: Who sets a college's diversity agenda? (2016, May 16). The Chronicle of Higher Education: Special Report. Retrieved from http://www.chronicle.com/specialreport/Diversity-in-Academe-Who-Sets/38.

Kerby, S. (2012). Ten reasons why we need diversity on campus. Center for American Progress Retrieved from https://www.americanprogress.org/issues/race/news/2012/10/09/41004/10reasons-why-we-need-diversity-on-college-campuses/

Kitchenham, A. (2008). The evolution of John Mezirow's transformative learning theory. Journal of Transformative Education, 6(2), 104-123.

https://doi.org/10.1177/1541344608322678

Lahiri, I. (2008). Creating a competency model for diversity and inclusion practitioners. The Conference Board: ID Report Number TCBP 005. Retrieved from: http://www.conferenceboard.org/ea/indexaa.cfm?ID=1781

Mezirow, J. (1991). Transformation dimension of adult learning. San Francisco: Jossey-Bass

Oakland University Fast Facts (2017) Retrieved from www.oakland.edu/fastfacts

Oakland University Mission (2017) Retrieved from https://oakland.edu/about/mission

Scott, C. L. (2014). Suggested theories, models, and frameworks used to address emerging diversity issues in the workforce. In M. Y. Byrd \& C. L. Scott (Eds.), Diversity in the workplace: 
Current issues and emerging trends (pp. 34-58). New York, NY: Routledge Taylor \& Francis Group.

Scott, C. L., \& Sims, J. (2014). Workforce diversity career development: A missing piece of the curriculum in academia. In C. Hughes (Ed.), Impact of diversity on organization and career development (pp. 129-149). Hershey, PA: IGI Global.

Scott, C. L., \& Sims, J. D. (Eds.). (2016). Developing workforce diversity programs, curriculum, and degrees in higher education. Hershey, PA: IGI Global. https://doi.org/10.4018/978-1-5225$\underline{0209-8}$

Sims, J. D. (2011). A muted voice on holy ground: Reflections on the dialectics experienced as an African American female professor in a Christian university. In M. N. Niles and N. S. Gordon (Eds)., Still searching for our mothers' gardens: Experiences of new, tenure-track women of color at 'majority' institutions (pp. 21-40). Lanham, MD: University Press of America.

Sims, J. D. (2015, May). Cool collaborations through interdisciplinary team-taught classes. Presented at the University of Central Oklahoma Provost's Advisory Council, Edmond, OK.

Sims, J. D., Anderson, P., \& Murray, A. (2012). First-generation student research engagement: What are they learning and why does it matter, MMA Fall Conference, Minneapolis, MN, 2012. Marketing Management Association Fall Conference Proceedings, 234-235. Retrieved from http://www.mmaglobal.org/publications/Proceedings/2012-MMA-Fall-Educators-ConferenceProceedings.pdf

Sims, J. D., Anderson, P., Neese, S., \& Sims, A. (2013). Enhancing student cognitive, affective, and behavioral development through undergraduate research, MMA Fall Conference, New Orleans, LA, 2013. Marketing Management Association Fall Conference Proceedings, 134-135. Retrieved from http://www.mmaglobal.org/publications/Proceedings/2013-MMA-FallEducators-Conference-Proceedings.pdf

Sims, J. D., Le, J., Emery, B., \& Smith, J. (2012). Beyond the quantitative headcount: Considering the un-captured qualitative impact of engaging undergraduate students in research. Council on Undergraduate Research Quarterly, 32(3), 23-27.

Sims, J. D., Le, J., \& Smith, J. (2011). Advancing the research pipeline: Enlisting undergraduate students in faculty co-authored research, MMA Fall Conference, St. Louis, MO, 2011. Marketing Management Association Fall Conference Proceedings, 238-239. Retrieved from http://www.mmaglobal.org/publications/Proceedings/2011-MMA-Fall-Educators-ConferenceProceedings.pdf

Sims, J. D., \& Scott, C. L. (2016, April). Two programs that transform students for professional workforce diversity readiness, presented at the University of Central Oklahoma Transformative Learning Conference, Oklahoma City, OK, 2016. UCO Transformative Learning Conference Proceedings, 2016. Oklahoma City, OK: University of Central Oklahoma, pp. 12-13. Retrieved 
from http://sites.uco.edu/central/tl/conference/conferencearchives/2016conference/2016\%20TL\%20Conference\%20Proceedings.pdf

Sims, J., Shuff, J., Neese, S., Lai, H.-L., Lim, O. F., \& Neese, A. (2016). Diverse student scholars: How a faculty member's undergraduate research program can advance workforce diversity learning. In C. L. Scott and J. D. Sims (Eds.). Expanding workforce diversity programs, curriculum, and degrees in higher education (pp. 62-73). Hershey, PA: IGI Global.

https://doi.org/10.4018/978-1-5225-0209-8.ch005

Whittaker, J. A., \& Montgomery, B. L. (2014). Cultivating institutional transformation and sustainable STEM diversity in higher education through integrative faculty development. Innovative Higher Education, 39, 263-275. https://doi.org/10.1007/s10755-013-9277-9 


\section{Author Information}

Chaunda L. Scott is an Associate Professor and Graduate Coordinator in the Department of Organizational Leadership in the School of Education and Human Services at Oakland University in Rochester, Michigan. Additionally, she is the Diversity and Inclusion Specialist for the Office of the Dean. In 2013, she was named one of the Top 25 Education Professors in Michigan by Online Schools Michigan. In 2015, she was a Fulbright Specialist scholar in Cape Town, South Africa.

Chaunda L. Scott

Associate Professor

Graduate Coordinator-Master of Training and Development Program

Department of Organizational Leadership

Diversity and Inclusion Specialist - Office of the Dean

School of Education and Human Services

Oakland University

2200 Squirrel Road

Rochester, MI 48309-4494

Email: cscott@oakland.edu

Telephone: (248) 224-9057 or (248) 370-4171

Jeanetta D. Sims is Assistant Dean in the Jackson College of Graduate Studies and Professor in the Marketing Department of the College of Business at the University of Central Oklahoma where she teaches courses in marketing and communication, and is accredited in public relations (APR). She has received university and national awards for her teaching (in 2014, 2012, and 2009) and for her scholarship (2018, 2017, 2016, 2013, 2012, 2010, 2009, 2008, and 2006). Along with numerous publications, she is co-editor of the annual UCO Transformative Learning Conference Proceedings, the Journal of Transformative Learning, and Developing Workforce Diversity Programs, Curriculum, and Degrees in Higher Education.

*Jeanetta D. Sims

Assistant Dean, Jackson College of Graduate Studies

Professor, Department of Marketing

Transformative Learning Scholar

University of Central Oklahoma

100 N. University Drive

Edmond, OK 73034

Email: jsims7@uco.edu

Telephone: (405) 974-2805 or (405) 974-3478

*Corresponding author 